\title{
ANTIPLATELET RESISTANCE IN PATIENTS WITH ATHEROSCLEROSIS
}

\author{
Sintija Locānè ${ }^{1, \#}$, Elīna Pūcīte ${ }^{1,2}$, Evija Miglāne ${ }^{1,2}$, Andrejs Millers ${ }^{1,2}$, Arina Novasa ${ }^{1}$, \\ Renija levina ${ }^{1}$, and Tatjana Muravska ${ }^{1}$

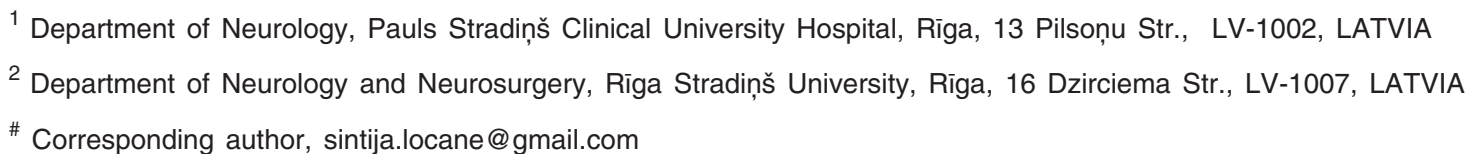

Communicated by Pēteris Stradiṇš

\begin{abstract}
Variable platelet response to aspirin and clopidogrel is a well-known phenomenon in patients with coronary artery disease and ischemic cerebral stroke. The objective of the present study was to evaluate the frequency and possible risk factors of antiplatelet resistance in patients with cerebrovascular and cardiovascular diseases. The VerifyNow system was used to evaluate adenosine-5-diphosphate and platelet P2YI2 receptor function in patients with cerebrovascular and cardiovascular disease, who received dual antiplatelet therapy. Aspirin resistance was defined as aspirin reaction units $(A R U) \geq 550$. Clopidogrel resistance was defined as Platelet Reaction Units $(P R U)>230$. In the group of cerebrovascular diseases there were $13.2 \%(n=27)$ patients with aspirin and $24.5 \%(n=50)$ with clopidogrel resistance. However, in the cardiovascular group there were $20 \%(n=9)$ aspirin and $11.1 \%(n=5)$ clopidogrel resistant patients. In the cerebrovascular group, aspirin resistant patients had a lower triglyceride level $(p=0.001, r=$ $0.26)$ than aspirin sensitive patients. Clopidogrel resistant patients had a significantly higher level of glycated haemoglobin (HbA1C) $(\mathrm{p}=0.016, r=023)$, triglycerides $(\mathrm{p}=0.033, \mathrm{r}=0.16)$ and lower level of high-density lipoproteins $(p=0.027, r=0.16)$ than clopidogrel sensitive patients. In the cardiovascular group, patients who were resistant to aspirin had a significantly higher high-density lipoprotein level $(\mathrm{p}=0.038, \mathrm{r}=0.31)$. No other factors differed significantly between the aspirin or clopidogrel resistant and sensitive patients in the cardiovascular group. Aspirin resistance was more common in patients with cardiovascular disease, and clopidogrel resistance in patients with cerebrovascular disease, although the difference was not significant. Our findings indicate that diabetes mellitus and an elevated level of lipoproteins could be risk factors for aspirin or clopidogrel resistance in patients with cerebrovascular diseases. Further studies should be conducted using larger patient cohorts with balanced groups of patients to investigate clinical aspects of antiplatelet resistance.
\end{abstract}

Key words: aspirin, clopidogrel, resistance, coronary artery disease, stroke.

\section{INTRODUCTION}

Atherosclerosis is a chronic systemic inflammatory disease affecting all arteries in the body, where platelet activation takes one of the main role in the pathogenesis (Badimon et al., 2012). For patients with coronary artery disease and ischemic stroke due to large arteries atherosclerosis, aspirin and/or clopidogrel are the first choice drugs for secondary prophylaxis (Balucani et al., 2010; Jones et al., 2018). However, antiplatelet effects of treatment are not observed in all patients. Therefore, some patients experience thrombotic events despite regular, adequate antiplatelet treatment according to guidelines for atherosclerotic cardiovascular and cerebrovascular diseases (Balucani et al., 2010; Jones et al., 2018).

Resistance is defined as inability of aspirin to reduce platelet production of thromboxane A2 and thereby platelet activation and aggregation (Feher et al., 2010). The cause of the antiplatelet resistance seems to be multifactorial. It can be divided in three categories: clinical, cellular and genetic causes (Wang et al., 2005). First, clinical causes of aspirin and clopidogrel resistance can vary from failure to prescribe the correct drugs to patient non-compliance. Patients may 
be compliant, but due to interactions with other medication (NSAIDs, particularly ibuprofen) (Catella-Lawson et al., 2001) or absorption difficulties (usage of proton pump inhibitors) (Mansour et al., 2009), the effect of antiplatelet medications is insufficient. Second, cause of resistance due to cellular factors could be inadequate suppression of platelet COX-1mediators. In addition, aspirin resistance has been attributed to COX-2 mRNA over-expression by platelets and endothelial cells. Clopidogrel resistance may be associated with inter-individual differences in P2Y12 receptors and the number of receptors an individual possesses, varying the levels of ADP release (Weber et al., 1999; Zimmermann et al., 2003). Finally, up to $30 \%$ of the variability in platelet activity can be explained by genetic factors (Feher et al., 2009). Common polymorphisms for aspirin resistance include polymorphisms in the platelet COX-1 and COX-2 genes (Goodman et al., 2008). Clopidogrel resistance has been linked to polymorphisms in genes involved in hepatic metabolism, intestinal absorption, and platelet surface receptors (Simon et al., 2009).

The prevalence of aspirin resistance ranges from 5.5 to $60 \%$ (Wang et al., 2006, Poulsen et al., 2007), whereas the prevalence of clopidogrel resistance has been reported from $5 \%$ to $44 \%$ (Gurbel and Tanry, 2007). The wide spectrum of the prevalence of antiplatelet resistance worldwide probably can be explained by mixed patient cohorts, variable antiplatelet dosage and differences of the methodology used to assess responsiveness to antiplatelet therapy.

It is possible that several conditions predispose to aspirin or clopidogrel failure beyond a biochemical diagnosis of resistance. The identification of patients who are likely to be resistant to antiplatelet therapy has important clinical implications. A number of studies have shown that aspirin and clopidogrel resistance is associated with increased risk of recurrent cardiovascular or cerebrovascular events (Snoep et al., 2007; Krasopoulos et al., 2008). Therefore, it is so important to identify these patients for the best individual approach of medical management.

The objective of the present study was to evaluate the frequency and possible risk factors of antiplatelet resistance in patients with cerebrovascular and cardiovascular diseases.

\section{MATERIALS AND METHODS}

The prospective observational study was conducted in Pauls Stradiňš Clinical University Hospital, where 249 patients were included. Patients older than 18 years with acute cerebrovascular or cardiovascular disorders were collected. Cerebrovascular disease was defined as acute ischemic stroke or transient ischemic attack, cardiovascular disease - acute myocardial infarct, coronary artery disease. There were 204 patients in the cerebrovascular and 45 patients in the cardiovascular group. All of them had been taking aspirin (100 mg) and clopidogrel (75 mg) at least for five days. Exclusion criteria were monotherapy with only one of the antiplatelet agents or absence of patient consent.
Blood tests were taken via venipuncture into a partial fill $3.2 \%$ sodium citrate vacuum collection tube. Two samples of blood were taken from right and left arm of each recruited patient to establish the presence of aspirin and clopidogrel resistance. The resistance tests were performed from the second blood sample.

Platelet inhibition was measured using the VerifyNow System analyser. The VerifyNow system mimics light transmittance aggregometry (classic method for studying platelet function), as it is a turbidimetric-based optical detection system that measures platelet-induced aggregation. The VerifyNow aspirin assay and VerifyNow P2Y12 assay were used to test the platelet aggregation in vitro (Krasopoulos et al., 2008).

Aspirin resistance was defined as Aspirin Reaction Units $(\mathrm{ARU})>550$. Clopidogrel resistance was defined as Platelet Reaction Units (PRU) > 230.

Basic demographic characteristics (age, sex), data on comorbidities (history of stroke or transient ischemic attack, coronary artery disease, atrial fibrillation, diabetes mellitus, arterial hypertension, chronic heart failure, peripheral artery disease) and use of medications were recorded on a standardised form.

This study was approved by the ethics committee at the Pauls Stradiňš University Hospital. All subjects provided written informed consent.

Descriptive statistics were used to analyse the demographics and clinical characteristics of the population. The normal distribution of data was tested with the Kolmogorov-Smirnov test. Categorical variables were presented as counts and percentages. Continuous variables were described as median and interquartile range ([IQR]). Categorical variables were analysed with the Chi-square test and continuous variables were compared with the Mann-Whitney U test. A two-sided $p$-value $<0.05$ was considered statistically significant. To understand whether differences were statistically meaningful, Cramer's V $(<0.3=$ small effect size, $0.3-0.5=$ medium effect size, $>0.5=$ large effect size) for the Pearson Chi-square test and $r(<0.3=$ small effect size, $0.3-0.5=$ medium effect size, $>0.5=$ large effect size) for the Mann-Whitney was used. Statistical analyses were performed using IBM SPSS Statistics (version 23 for Windows, IBM Corp., Somers, NY, USA).

\section{RESULTS}

The study involved 249 patients. Patients were divided in two different groups. There were 204 patients in the cerebrovascular disease group and 45 patients in the cardiovascular disease group. The study groups were compared to determine whether there was any difference in demographic and clinical characteristics that could influence the frequency of the resistance (Table 1). Regarding demographic characteristics, there were more males in cerebrovascular group $(66.7 \%)$ and more females in cardiovascular group 
DEMOGRAPHIC AND CLINICAL CHARACTERISTICS OF THE CEREBROVASCULAR AND CARDIOVASCULAR GROUPS

\begin{tabular}{|c|c|c|c|c|}
\hline & & $\begin{array}{c}\text { Cerebro- } \\
\text { vascular group, } \\
\mathrm{n}=204\end{array}$ & $\begin{array}{c}\text { Cardio-v } \\
\text { ascular group, } \\
\mathrm{n}=45\end{array}$ & $\begin{array}{c}p \\
\text { value }\end{array}$ \\
\hline \multicolumn{2}{|c|}{ Age (median, IQR) } & 69 [61-77] & $66[60.5-72]$ & 0.241 \\
\hline \multirow{2}{*}{ Sex } & Female $(\mathrm{n}, \%)$ & $68(33.3 \%]$ & $22(48.9 \%)$ & \multirow{2}{*}{0.049} \\
\hline & Male (n, \%) & $136(66.7 \%)$ & $23(51.1 \%)$ & \\
\hline \multicolumn{2}{|c|}{$\begin{array}{l}\text { Transient ischemic attack, } \\
(\mathrm{n}, \%)\end{array}$} & $9(4.4 \%)$ & 0 & 0.151 \\
\hline \multicolumn{2}{|c|}{ Prior stroke $(\mathrm{n}, \%)$} & $69(33.8 \%)$ & $3(6.7 \%)$ & $<0.001$ \\
\hline \multicolumn{2}{|c|}{ Prior myocardial infarct $(\mathrm{n}, \%)$} & $48(23.5 \%)$ & $19(42.2 \%)$ & 0.010 \\
\hline \multirow{2}{*}{$\begin{array}{l}\text { Heart failure } \\
(\mathrm{n}, \%)\end{array}$} & II class NYHA & $44(62.9 \%)$ & $21(70 \%)$ & 0.010 \\
\hline & III class NYHA & $26(37.1 \%)$ & $3(10 \%)$ & 0.250 \\
\hline \multirow{2}{*}{$\begin{array}{l}\text { Arterial hyper- } \\
\text { tension }(\mathrm{n}, \%)\end{array}$} & 2 grade & $115(74.2 \%)$ & $32(74.4 \%)$ & 0.069 \\
\hline & 3 grade & $21(13.5 \%)$ & $3(7 \%)$ & 0.455 \\
\hline \multicolumn{2}{|c|}{ Atrial fibrillation (n, \%) } & $16(7.8 \%)$ & $6(13.3 \%)$ & 0.240 \\
\hline \multicolumn{2}{|c|}{ Peripheral artery disease $(\mathrm{n}, \%)$} & $9(4.4 \%)$ & $6(13.3 \%)$ & 0.023 \\
\hline \multicolumn{2}{|c|}{ Diabetes mellitus (n, \%) } & $43(21.1 \%)$ & $10(22.2 \%)$ & 0.865 \\
\hline
\end{tabular}

IQR, interquartile range; NYHA, New York Heart Association.

In bold - statistically significant difference in the results of both groups.

$(48.9 \%)(p=0.049)$. Prior stroke before enrollment in the study was more frequent in the cerebrovascular group $33.8 \%(\mathrm{n}=69 ; p<0.001)$, and myocardial infarct was more common in the cardiovascular group $-42.2 \%(\mathrm{n}=19 ; p=$ 0.01 ). The frequency of patients with peripheral artery disease was higher in the cardiovascular group $-13.3 \%$ patients $(\mathrm{n}=6 ; p=0.023)$.

Regarding administered medications, beta blockers (nebivolol, bisoprolol, metoprolol) were more often used in the cardiovascular group $(p=0.03)$. There was no statistically significant difference in frequency of other used medications (AKE inhibitors, loop diuretics, amlodipine, verospiron, medications for diabetes mellitus) between the two groups (Table 2).

In the cerebrovascular group higher cholesterol (4.93 $\mathrm{mmol} / 1$ [4.05-5.96], $p=0.002$ ) and low density lipoprotein
MEDICATIONS USED IN THE CEREBROVASCULAR AND CARDIOVASCULAR GROUPS

\begin{tabular}{lcccc}
\hline & $\begin{array}{c}\text { Cerebrovascular } \\
\text { group, } \mathrm{n}=204\end{array}$ & $\begin{array}{c}\text { Cardiovascular } \\
\text { group, } \mathrm{n}=45\end{array}$ & $p$ value \\
\hline Perindopril, n, \% & $135(66.2 \%)$ & $29(64.4 \%)$ & 0.824 \\
Hypothiasid, n, \% & $11(5.4 \%)$ & 0 & 0.111 \\
Telmisartan, n, \% & $7(3.4 \%)$ & $3(6.7 \%)$ & 0.317 \\
Loop diuretics, n, \% & $38(18.6 \%)$ & $7(15.6 \%)$ & 0.628 \\
Amlodipin, n, \% & $101(49.5 \%)$ & $20(44.4 \%)$ & 0.538 \\
Verospiron, n, \% & $7(3.4 \%)$ & $3(6.7 \%)$ & 0.317 \\
Nebivolol, n, \% & $5(2.5 \%)$ & $10(22.2 \%)$ & $<\mathbf{0 . 0 0 1}$ \\
Bisoprolol, n, \% & $36(17.6 \%)$ & $21(46.7 \%)$ & $<\mathbf{0 . 0 0 1}$ \\
Metoprolol, n, \% & $7(3.4 \%)$ & $5(11.1 \%)$ & $\mathbf{0 . 0 2 9}$ \\
L-Thyroxin, n, \% & $7(3.4 \%)$ & $4(8.9 \%)$ & 0.107 \\
Insulin, n, \% & $17(8.3 \%)$ & $2(4.4 \%)$ & 0.374 \\
Metformin, n, \% & $25(12.3 \%)$ & $6(13.3 \%)$ & 0.843 \\
Janumet, n, \% & $3(1.5 \%)$ & $1(2.2 \%)$ & 0.717 \\
Diaprel, n, \% & $5(2.5 \%)$ & $1(2.2 \%)$ & 0.928 \\
Other drugs, n, \% & $200(98 \%)$ & $40(88.9 \%)$ & 0.003
\end{tabular}

In bold - statistically significant difference in the results of both groups.

(2.91 mmol/1 [2.15-3.89], $p<0.001)$ levels were observed, whereas troponin (84.0 ng/l [6-771.7], $p=0.007)$ and high density lipoprotein $(1.27 \mathrm{mmol} / \mathrm{l}$ [1.06-1.46], $p=0.052)$ level were higher in the cardiovascular group. Results of other blood tests (HbA1c, triglycerids, CRP, leukocytes, ESR) revealed no significant difference between the cardiovascular and cerebrovascular groups.

In the cerebrovascular group there were $13.2 \%(\mathrm{n}=27)$ patients with aspirin and $24.5 \%(n=50)$ patients with clopidogrel resistance. However, in the cardiovascular group there were $20 \%(n=9)$ aspirin and $11.1 \%(n=5)$ clopidogrel resistant patients. Although frequency of resistance to aspirin or clopidogrel did not differ significantly between the groups $(p>0.05)$, there was a tendency that aspirin resistance was more frequent in the cardiovascular group, and clopidogrel resistance in the cerebrovascular group (Figure 1).

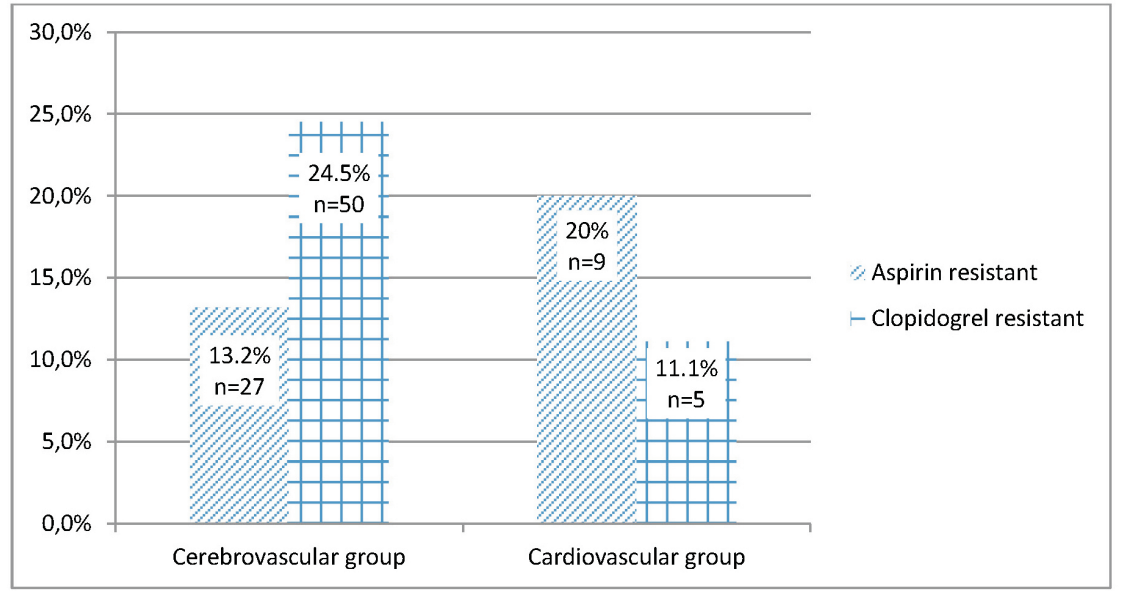

Fig. 1. Frequency of aspirin and clopidogrel resistance in the cerebrovascular and cardiovascular groups. 
The analysis of possible risk factors was performed in each study group to frame the resistance of antiplatelet medications. The average age of aspirin sensitive patients in then cerebrovascular group was 67 [61-76] years, and of aspirin resistant $-76[68-78]$ years $(p=0.005, \mathrm{r}=0.2)$. The difference between aspirin sensitive and resistant patients regarding gender, comorbidities as diabetes mellitus, arterial hypertension, atrial fibrillation, peripheral artery disease was not statistically significant. We found that patients in the cerebrovascular group who were resistant to aspirin showed significantly lower triglyceride levels than those of aspirin sensitive patients (resistant $1.1 \mathrm{mmol} / \mathrm{l}$ [0.8-1.3], sensitive $1.5 \mathrm{mmol} / \mathrm{l}[1.2-2.3], p=0.001 ; \mathrm{r}=0.26)$. Clopidogrel resistant patients more often had diabetes mellitus (40.9\% ( $\mathrm{n}=18)$ vs $15.6 \%(\mathrm{n}=25), \quad p=0.001$, Cramers $\mathrm{V}=0.255)$ and showed significantly higher level of $\mathrm{HbA}_{1} \mathrm{C}$ (resistant $6.7 \%$ [5.7-8.7]; sensitive 5.8\% [ 5.5-6.4]; $p=$ $0.016 ; \mathrm{r}=023$ ), triglycerides (resistant $1.7 \mathrm{mmol} / 1$ [1.3-2.6], sensitive $1.4 \mathrm{mmol} / \mathrm{l}[1.1-2.0], p=0.033, \mathrm{r}=$ 0.16 ) and lower level of high-density lipoproteins (resistant $1.1 \mathrm{mmol} / \mathrm{l}$ [0.8-1.3], sensitive $1.2 \mathrm{mmol} / 1$ [1.0-1.4]; $p=$ $0.027 ; r=0.16)$. As there were more patients with a diabetes mellitus in clopidogrel resistant patients, therefore hypoglicaemics were more frequently used in this group - metformin (resistant 18.2\% $(\mathrm{n}=8)$, sensitive $6.9 \%(\mathrm{n}=11), p=$ $0.036)$, sitagliptin/metformin (resistant $9.1 \%(n=4)$, sensitive $0.6 \%(\mathrm{n}=1), p=0.008)$, insulin (resistant $18.2 \%(\mathrm{n}=$
8), sensitive $5.6 \%(\mathrm{n}=9), p=0.013)$. Other laboratory data are listed in table (Table 3).

In the cardiovascular group, a significantly higher highdensity lipoprotein level was observed in aspirin resistant (sensitive $1.18 \mathrm{mmol} / \mathrm{l}$ [1.04-1.25] and resistant 1.45 $\mathrm{mmol} / \mathrm{l}[1.30-1.74], p=0.038, \mathrm{r}=0.31)$, than in aspirin sensitive patients. There was no statistically significant difference of comorbidities, medications use or other laboratory data between aspirin and clopidogrel resistant and sensitive patients in the cardiovascular group (Table 4).

\section{DISCUSSION}

Aspirin and clopidogrel are first choice antiplatelet agents for the secondary prevention of ischemic stroke or myocardial infarction (Wong et al., 2013; Motovska et al., 2017). However, if they fail to inhibit platelet aggregation it may increase the rate of recurrent clinical events. In this study, the frequency of aspirin resistance was $13.2 \%$ and frequency of clopidogrel resistance was $24.5 \%$ in the cerebrovascular group. In the cardiovascular group, $20 \%$ aspirin and $11.1 \%$ clopidogrel resistant patients were detected.

Our data do not differ much from results of other studies, where pooled prevalence of high on-treatment of platelet reactivity (HTPR) was 24\% (95\%CI: 20-27\%); in subgroup

Table 3

RISK FACTORS IN ASPIRIN AND CLOPIDOGREL SENSITIVE AND RESISTANT PATIENTS IN THE CEREBROVASCULAR GROUP

\begin{tabular}{l|c|c|c|c|c|c|c|c}
\hline & $\begin{array}{c}\text { Aspirin sensitive, } \\
\mathrm{n}=177\end{array}$ & $\begin{array}{c}\text { Aspirin resistant, } \\
\mathrm{n}=27\end{array}$ & $p$ value & Effect size & $\begin{array}{c}\text { Clopidogrel } \\
\text { sensitive, } \\
\mathrm{n}=160\end{array}$ & $\begin{array}{c}\text { Clopidogrel } \\
\text { resistant, } \\
\mathrm{n}=44\end{array}$ & $p$ value & Effect size \\
\hline $\begin{array}{l}\text { HbA1C [median, IQR] } \\
\begin{array}{l}\text { High-density lipoprotein, } \\
\text { [median, IQR] }\end{array}\end{array}$ & $6 .[05.5-6.8]$ & $5.9[5.5-6.3]$ & 0.56 & $r=0.06$ & $5.8[5.5-6.4]$ & $6.7[5.7-8.7]$ & $\mathbf{0 . 0 1 6}$ & $\boldsymbol{r}=\mathbf{0 . 2 3}$ \\
$\begin{array}{l}\text { Low-density lipoprotein, } \\
\text { [median, IQR] }\end{array}$ & $1.1[0.9-1.4]$ & $1.2[1.0-1.5]$ & 0.16 & $r=0.1$ & $1.2[1.0-1.4]$ & $1.1[0.8-1.3]$ & $\mathbf{0 . 0 2 7}$ & $\boldsymbol{r}=\mathbf{0 . 1 6}$ \\
$\begin{array}{l}\text { Triglycerids [median, IQR] } \\
\text { Cholesterol [median, IQR] }\end{array}$ & $1.5[1.1-3.9]$ & $2.9[2.2-3.9]$ & 0.65 & $r=0.03$ & $2.9[2.2-3.9]$ & $3.0[2.0-3.7]$ & 0.799 & $r=0.02$ \\
& $5.1[4.1-6.0]$ & $1.1[0.8-1.3]$ & $\mathbf{0 . 0 0 1}$ & $\boldsymbol{r}=\mathbf{0 . 2 6}$ & $1.4[1.1-2.0]$ & $1.7[1.3-2.6]$ & $\mathbf{0 . 0 3 3}$ & $\boldsymbol{r}=\mathbf{0 . 1 6}$ \\
\end{tabular}

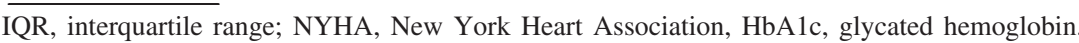

In bold - statistically significant difference in the results of both groups.

Table 4

RISK FACTORS IN ASPIRIN AND CLOPIDOGREL SENSITIVE AND RESISTANT PATIENTS IN THE CARDIOVASCULAR GROUP

\begin{tabular}{|c|c|c|c|c|c|c|c|c|}
\hline & $\begin{array}{l}\text { Aspirin sensitive, } \\
\qquad \mathrm{n}=36\end{array}$ & $\begin{array}{l}\text { Aspirin resistant, } \\
\mathrm{n}=9\end{array}$ & $p$ value & Effect size & $\begin{array}{c}\text { Clopidogrel } \\
\text { sensitive, } \\
n=40\end{array}$ & $\begin{array}{l}\text { Clopidogrel } \\
\text { resistant, } \\
\mathrm{n}=5\end{array}$ & $p$ value & Effect size \\
\hline HbA1C (median, IQR) & $6.1[5.8-6.6]$ & $5.9[5.6-6.1]$ & 0.409 & $\mathrm{r}=0.13$ & $6[5.7-6.4]$ & $6.3[5.9--6.6]$ & 0.650 & $\mathrm{r}=0.077$ \\
\hline $\begin{array}{l}\text { High-density lipoprotein, } \\
\text { (median, IQR) }\end{array}$ & $1.18[1.04-1.25]$ & $1.45[1.30-1.74]$ & 0.038 & $\mathbf{r}=\mathbf{0 . 3 1}$ & $1.23[1.06-1.38]$ & $1.45[1.30-1.47]$ & 0.234 & $r=0.167$ \\
\hline $\begin{array}{l}\text { Low-density lipoprotein, } \\
\text { (median, IQR) }\end{array}$ & $2.22[1.57-3.09]$ & $1.72[1.6-2.42]$ & 0.476 & $\mathrm{r}=0.11$ & $2.22[1.54-3.09]$ & $1.72[1.71-2.08]$ & 0.586 & $r=0.086$ \\
\hline $\begin{array}{l}\text { Triglycerids, (median, } \\
\text { IQR) }\end{array}$ & $1.66[1.06-2.25]$ & 1.12 [1.03-1.46] & 0.172 & $r=0.207$ & $1.5[1.03-2.9]$ & $1.31[1.12-2.10]$ & 0.875 & $\mathrm{r}=0.027$ \\
\hline Cholesterol, (median, IQR) & $4.09[3.48-5.16]$ & 3.93 [3.53-4.39] & 0.686 & $\mathrm{r}=0.06$ & $3.96[3.44-5.16]$ & $4.39[3.53-4.5]$ & 0.958 & $\mathrm{r}=0.011$ \\
\hline
\end{tabular}

IQR, interquartile range; NYHA, New York Heart Association, HbA1c, glycated haemoglobin.

In bold - statistically significant difference in the results of both groups. 
analyses, the prevalence of HTPR on aspirin was $23 \%$ (95\%CI: 20-28\%), on clopidogrel 27\% (95\%CI: 22-32\%) and on dual antiplatelet treatment (DAPT) $7 \%$ (95\%CI: 5-10\%) (Fiolaki et al., 2017). Our study revealed that in the cerebrovascular group the age of patients and the level of triglycerides were associated with aspirin resistance. Aspirin resistant patients were older (76 [68-78], $p=0.005$, but these results should be interpreted with caution, because effect size of statistical significance was low. An interesting finding of our study is that level of triglycerides was lower in the group of aspirin resistant patients than in aspirin sensitive patients), which is not congruent with other studies where levels of triglycerides were significantly increased in patients with aspirin resistance (Karepov et al., 2008). A possible explanation of our results might be due to the small number of patients and unbalanced number of patients for group comparison.

Revealed factors associated with clopidogrel resistance were diabetes mellitus, elevated levels of $\mathrm{HbA1C}$, high density lipoproteins, triglycerides, number of leukocytes, and treatment with hypoglycemic like metformine and sitagliptin/metformin in our study. Prior studies have observed that patients with diabetes showed increased platelet aggregation and activation and were more frequently aspirin and clopidogrel resistant than healthy (or antiplatelet treatment sensitive) patients (Angiolillo et al., 2005). There is accumulating evidence that platelet hyperactivity in patients with diabetes is mediated by insulin resistance and increased P2Y12 signalling (Ferreira et al., 2006).

Patients of the cardiovascular group who were resistant to aspirin showed significantly higher levels of high-density lipoprotein, which is not consistent with data from other studies, where low density lipoprotein was associated with aspirin and clopidogrel resistance. A possible explanation of our results is that in the cardiovascular group there were patients with acute myocardial infarct and coronary heart disease who used high doses of hypolipidemic medications that could make serious changes in the lipoprotein profile. Other factors were non-significant predictors of resistance to aspirin and clopidogrel in the cardiovascular group.

In this study two groups of patients with atherosclerotic vascular diseases were analysed. Although the risk factors and pathogenesis of atherosclerosis did not differ within the vascular territories there were some diverse clinical and laboratory parameters of antiplatelet resistance in the study groups. The differences could be explained by unequal sample size and probably by polypharmacy bounded to comorbidities, for example, use of proton pump inhibitors or hypolipidemic medications (Freedman et al., 2009). Therefore, further trials are needed to study the interaction of antiagregants and other medication dosage and the length of use in vitro as well as in vivo. Furthermore, there is still no clear answer in the literature whether patients with antiagregant resistance in vitro have also resistance in vivo whether they have increased rate of reccurent cardio- and cerebrovascular events.
Some limitations of the study should be taken into account. The major limitation of the study was small and unequal sample sizes in both groups. None of the currently available platelet function assays, including the VerifyNow system, has been sufficiently validated and standardised to monitor antiplatelet therapies. In addition, this was a cross-sectional study, and therefore clinical significance of biochemical antiplatelet resistance could not be evaluated.

\section{CONCLUSIONS}

In summary aspirin resistance was more common in patients with cardiovascular disease whereas clopidogrel resistance - in patients with cerebrovascular disease, although the difference was not significant. Our findings indicate that diabetes mellitus and elevated levels of lipoproteins could be risk factors for aspirin or clopidogrel resistance in patients with cerebrovascular diseases. Further studies should be conducted using larger patient cohorts with balanced groups of patients to investigate clinical aspects of antiplatelet resistance.

\section{ACKNOWLEDGEMENTS}

This study was funded by the National Research Programme BIOMEDICINE 2014-2017, Ministry of Education and Sciences, Republic of Latvia.

\section{REFERENCES}

Angiolillo, D. J., Fernandez-Ortiz, A., Bernardo, E., Ramirez, C., Sabate, M., Jimenez-Quevedo, P., Macaya, C. (2005). Platelet function profiles in patients with type 2 diabetes and coronary artery disease on combined aspirin and clopidogrel treatment. Diabetes, 54 (8), 2430-2435.

Badimon, L., Padró, T., Vilahur, G. (2012). Atherosclerosis, platelets and thrombosis in acute ischaemic heart disease. Eur. Heart J. Acute Cardiovasc. Care, 1 (1), 60-74.

Balucani, C., Barlinn, K., Zivanovic, Z., Parnetti, L., Silvestrini, M., Alexandrov, A. V. (2010). Dual antiplatelet therapy in secondary prevention of ischemic stroke: A ghost from the past or a new frontier? Stroke Res. Treat., DOI 2010:427418.

Catella-Lawson, F., Reilly, M. P., Kapoor, S. C., et al. (2001). Cyclooxygenase inhibitors and the antiplateleteffects of aspirin. New Engl. J. Med., 345, 1809-1817.

Feher, G., Feher, A., Pusch, G., et al. (2010). Clinical importance of aspirin and clopidogrel resistance. World J. Cardiol., 2 (7), 171-186.

Feher, G., Feher, A., Pusch, G., Lupkovics, G., Szapary, L., Papp, E. (2009). The genetics of antiplatelet drug resistance. Clin. Genet., 75 (1), 1-18.

Ferreira, I. A., Mocking, A. I., Feijge, M. A., et al. (2006). Platelet inhibition by insulin is absent in type 2 diabetes mellitus. Arterioscler. Thromb. Vasc. Biol., 26, 417-422.

Fiolaki, A., Katsanos, A. H., Kyritsis, A. P., Papadaki, S., Kosmidou, M., Moschonas, I. C. Giannopoulos, S. (2017). High on treatment platelet reactivity to aspirin and clopidogrel in ischemic stroke: A systematic review and meta-analysis. J. Neurol. Sci., 376, 112-116.

Freedman, J. E., Hylek, E. M. (2009). Clopidogrel, genetics, and drug responsiveness. New Engl. J. Med., 360 (4), 411-413.

Goodman, T., Ferro, A., Sharma, P. (2008). Pharmacogenetics of aspirin resistance: a comprehensive systematic review. Brit. J. Clin. Pharmacol., 66 (2), 222-232. 
Gurbel, P. A., Tantry, U. S. (2007). Clopidogrel resistance? Thrombosis Res., 120 (3), 311-321.

Karepov, V., Tolpina, G., Kuliczkowski, W., Serebruany, V. (2008). Plasma triglycerides as predictors of platelet responsiveness to aspirin in patients after first ischemic stroke. Cerebrovas. Dis., 26 (3), 272-276.

Krasopoulos, G., Brister, S. J., Beattie,W. S., Buchanan, M. R. (2008). Aspirin "resistance" and risk of cardiovascular morbidity: Systematic review and meta-analysis. BMJ, 336, 195-198.

Mansour, K., Taher, A. T., Musallam, K. M., Alam, S. (2009). Aspirin resistance. Adv. Hematol. DOI: 10.1155/2009/937352. Available from: https://www.ncbi.nlm.nih.gov/pubmed/19960045 (accessed 15.05.2019).

Motovská, Z., Varvarovský, I., Ostádal, P. (2017). ESC focused update on dual antiplatelet therapy in coronary artery disease developed in collaboration with EACTS. Summary of the document prepared by the Czech Society of Cardiology. Cor et Vasa, 59 (6), e592-e612.

Poulsen, T. S., Jorgensen, B., Korsholm, L., et al. (2017). Prevalence of aspirin resistance in patients with an evolving acute myocardial infarction. Thromb. Res.,119, 555-562.

Jones, R., Arps, K., Davis, D. M., Blumenthal, R., Martin, S. S. (2018). Clinician Guide to the ABCs of Primary and Secondary Prevention of Atherosclerotic Cardiovascular Disease. Available from: https://www.acc.org/latest-in-cardiology/articles/2018/03/30/18/34/ clinician-guide-to-the-abcs (accessed 15.05.2019).
Simon, T., Verstuyft, C., Mary-Krause, M., et al. (2009). Genetic determinants of response to clopidogrel and cardiovascular events. New Engl. J. Med., 360 (4), 363-375.

Snoep, J. D., Hovens, M. M., Eikenboom, J. C., van der Bom, J. G., Jukema, J. W., Huisman, M. V. (2007). Clopidogrel nonresponsiveness in patients undergoing percutaneous coronary intervention with stenting: A systematic review and meta-analysis. Amer. Heart J., 154, 221-231.

Wang, C. B., Hu, D. Y., Shi, X. B., et al. (2006). Aspirin resistance in patients taking small dose of aspirin. Zhongguo Wei Zhong Bing Ji Jiu Yi Хие, 18, 219-223.

Wang, T. H., Bhatt, D. L., Topol, E. J. (2005). Aspirin and clopidogrel resistance: An emerging clinical entity. Eur. Heart J., 27 (6), 647-654.

Weber, A. A., Zimmerman, K. C., Meyer-Kirchrath, J, Schor, K. (1999). Cyclooxygenase- 2 in human platelets as a possible factor in aspirin resistance. Lancet, 353, 900.

Wong, K. S. L., Wang, Y., Leng, X., Mao, C., Tang, J., Bath, P. M. W., Wang, Y. (2013). Early dual versus mono antiplatelet therapy for acute non-cardioembolic ischemic stroke or transient ischemic attack. Circulation, 128 (15), 1656-1666.

Zimmermann, N., Wenk, A., Kim, U., Kienzle, P., Weber, A.-A., Gams, E., Schror, K., Hohlfeld, T. (2003). Functional and biochemical evaluation of platelet aspirin resistance after coronary artery bypass surgery. Circulation, 108, 542-547.

\section{ANTIAGREGANTU REZISTENCE PACIENTIEM AR ATEROSKLEROZI}

Trombocìtu funkcionālās aktivitātes izmaiṇas, reaǵéjot uz aspirīna un klopidogrela terapiju, ir ilgstoši pētīta parādība pacientiem ar cerebrovaskulārām un kardiovaskulārām slimībām. Pētījuma mērḳis bija noteikt acetilsalicilskābes (aspirīna) un klopidogrela rezistences sastopamības biežumu un izvērtēt iespējamos riska faktorus rezistences attīstībai kardiovaskulāru un cerebrovaskulāru pacientu grupās. VerifyNow sistēma tika izmantota, lai izvērtētu adenozīn-5 difosfāta un trombocītu P2Y12 receptoru funkcionalitāti abās pacientu grupās, lietojot duālu antiagregantu terapiju. Aspirīna rezistence pacientiem tika definēta ja aspirīna rezistences vienības (ARU) bija 550, bet klopidogrela rezistence — ja trombocītu rezistences vienības (PRU) bija 230. Cerebrovaskulāru slimību grupā 13.2\% $(\mathrm{n}=27)$ pacientiem tika konstatēta aspirīna, 24.5\% $(n=50)$ - klopidogrela rezistence. Kardiovaskulāru pacientu grupā $20 \%(n=9)$ tika konstatēta aspirīna un $11.1 \%(\mathrm{n}=5)$ klopidogrela rezistence. Cerebrovaskulāru slimību grupā aspirīna rezistentiem pacientiem tika novērots zemāks triglicerīdu līmenis $(p=0.001, \mathrm{r}=0.26)$, turpretim klopidogrela rezistentiem pacientiem tika novērots augstāks glikolizētā hemoglobīna $(H b A 1 c)(p=$ $0.016, \mathrm{r}=0.23)$, triglicerīdu $(p=0.033, \mathrm{r}=0.16)$ un zemāks augsta blīvuma lipīdu līmenis $(p=0.027, \mathrm{r}=0.16)$, salīdzinot ar aspirīna sensitīviem pacientiem. Kardiovaskulāro pacientu grupā tika konstatēts ievērojami augstāks augsta blīvuma lipīdu līmenis $(p=0.038, \mathrm{r}=$ 0.31) aspirīna rezistentiem pacientiem. Secinājumi: tendence uz aspirīna rezistenci biežāk tika novērota pacientiem ar kardiovaskulārām saslimšanām, bet klopidogrela rezistence - cerebrovaskulāru saslimšanu grupā, lai gan statistiski šì atškirība nav būtiska. Mūsu pētījums parāda ka cukura diabēts un paaugstināts lipoproteīnu līmenis var būt riska faktors aspirīna un klopidogrela rezistences attīstībai cerebrovaskulāru saslimšanu grupā. Ir nepieciešami tālāki izmeklējumi plašākām un sabalansētām pacientu grupām, lai pētītu antiagregantu rezistences klīniskos aspektus. 